\title{
OCCURRENCE OF CRUDE OIL DEGRADING BACTERIA IN GASOLINE AND DIESEL STATION SOILS
}

\author{
Pattanathu K.S.M. Rahman ${ }^{* 1}$, Thahira-Rahman ${ }^{1}$, Perumal Lakshmanaperumalsamy ${ }^{2}$, \\ and Ibrahim M. Banat ${ }^{1}$
}

1. Biotechnology Group, School of Biological and Environmental Sciences,

University of Ulster, Coleraine, County Londonderry, Northern Ireland - BT52 1SA.

2. Department of Environmental Sciences, Bharathiar University,

Coimbatore - 641 046, Tamilnadu, India.

* Corresponding Author Present address:

Dr Pattanathu K.S.M. Rahman

Chemical and Bioprocess Engineering Group

School of Science and Engineering

Teesside University, Middlesbrough - TS1 3BA

Teesvalley, United Kingdom.

Tel: $\quad+44-1642-384669$

Email: p.rahman@tees.ac.uk

Running title: Biodegradation of petroleum hydrocarbons 


\section{SUMMARY}

Microbial enumeration and identification were carried out on several oil contaminated soil samples collected from gasoline and diesel stations. Bacteria were the most dominant microbiota and were therefore classified to generic level. Eleven main genera were detected and Corynebacterium was the predominant genus in all the samples. Biochemical characterisation and substrate utilisation showed high percentage of lipolytic ability combined with high inorganic nitrogen utilisers. The ability of these cultures to degrade crude oil was tested individually and in mixed bacterial consortium at different temperatures and $\mathrm{pH}$ values. Maximum crude oil biodegradation of $78 \%$ was achieved using a bacterial consortium containing five cultures (Micrococcus sp. GS2-22, Corynebacterium sp. GS5-66, Flavobacterium sp. DS5-73, Bacillus sp. DS6-86 and Pseudomonas sp. DS10-129) with $1 \%$ crude oil at $30^{\circ} \mathrm{C}$ and $\mathrm{pH}$ 7.5. Such a consortium may be useful for bioaugmentation of oil contaminated environments. 


\section{INTRODUCTION}

Petroleum continues to serve as the principle source of energy. Wide scale production, transport, use and disposal of petroleum globally has made it a lead contaminant in both prevalence and quantity in the environment. As a result of the increase in automobiles, the number of gasoline/diesel stations and automobile service stations is ever increasing. In gasoline, diesel stations and service stations, oil is spilled during transfer and servicing operations. During accidental spills, action will be taken to remove or remediate or recover the contaminant immediately, whereas in the gasoline and diesel stations the spills due to leakage may be small but continuous and prolonged. Because of its persistence, the chance for groundwater contamination is greater.

The addition of hydrocarbons to an ecosystem may result in a selective increase in microorganisms capable of utilising the hydrocarbons and those that are capable of utilising metabolites produced by the hydrocarbon-utilisers (Venkateswaran et al. 1995; Ferrari et al. 1996). The enhancement or reduction will depend upon the chemical composition of the contaminating hydrocarbons and on the species of microorganisms present within the microbial community of the particular ecosystem (Atlas 1995).

The Gulf War and an increasing trend in tanker accidents have focussed attention on the problem of hydrocarbon contamination in the environment. The traditional methods to cope with oil spills are mainly through physical containment and collection using floating booms, applications of adsorbents such as straw, shredded polyurethane or porous volcanic glasses and/or dispersal by detergents (Ollis 1992). Biological methods have an edge over the physico-chemical treatment regimes in removing spills as they offer in situ biodegradation of oil fractions by the microorganisms (Ferrari et al.1996) 
The fate of petroleum hydrocarbons in the environment, including biodegradation, is largely determined by abiotic factors, which influence the extent of weathering. This paper describes the microbial population and microbial diversity of samples from gasoline and diesel stations and explores the possibility of using selected bacterial cultures and bacterial consortium to degrade Bombay high crude oil at various environmental conditions.

\section{MATERIALS AND METHODS}

\section{Screening of samples}

The soil samples (100g each) were collected from ten Gasoline spilled (GS) and diesel spilled (DS) stations for the isolation of oil degrading microorganisms. The samples were collected in pre-sterilised glass bottles and transported to the laboratory for analysis. Enumeration and isolation of heterotrophic bacteria, actinomycetes and fungi was carried out through serial dilution-agar plating technique using Nutrient agar, Kuster's agar and Rose Bengal agar medium (HIMEDIA) respectively.

\section{Characterisation of bacteria}

The isolates were grouped to various genera as per Bergey's Manual of Determinative Bacteriology (Holt et al., 1994). These cultures were characterised depending on their morphology, gram staining, spore staining, motility, oxidase, catalase, oxidation fermentation, gas production, ammonia formation, nitrate and nitrite reduction, indole production test, methyl-red and Voges-Proskauer test, citrate and mannitol utilisation test, hydrolysis of casein, gelatin, starch, urea and lipid (Aaranson 1970). 


\section{Growth of bacteria on crude oil}

The bacterial cultures isolated from oil spilled environment were inoculated in Mineral salts medium (Kennedy et al., 1975) with 1\% Bombay High crude oil as carbon source. It was kept in the shaker at $200 \mathrm{rpm}$ at $30^{\circ} \mathrm{C}$ for a period of seven days. The growth was recorded and categorized spectrophotometrically as low growth with optical density (OD) in the range 0.21-0.4, moderate growth (OD 0.41-0.6), high growth (OD 0.61-0.8) and excellent growth (OD 0.81-1.0) all measured at 620nm.

\section{Preparation of inoculum}

The bacterial isolates that exhibited excellent growth on crude oil, Micrococcus sp. GS222, Bacillus sp. DS6-86, Corynebacterium sp. GS5-66, Flavobacterium sp. DS5-73 and Pseudomonas sp. DS10-129, were selected. A loopful of culture was inoculated into 100ml sterile nutrient broth. The flasks were incubated and shaken at $200 \mathrm{rpm}$, for $12 \mathrm{~h}$ at $30^{\circ} \mathrm{C}$. One $\mathrm{ml}$ volumes of the culture broth from each of the above five isolates were mixed to prepare mixed bacterial consortium.

\section{Degradation of crude oil}

Individual bacterial cultures and bacterial consortium (1.0\%) were transferred to $250 \mathrm{ml}$ conical flasks, each containing $100 \mathrm{ml}$ of sterile defined mineral salts medium with $1 \%$ Bombay High (BH) crude oil. An uninoculated control was also studied concurrently. The flasks were incubated at $30^{\circ} \mathrm{C}$ and shaken at $200 \mathrm{rpm}$ for 20 days. At 2-day intervals, a set of flasks was used for the enumeration of microbial population and estimation of crude oil content 
spectrophotometrically as described in Rahman et al. (2002). Degradation was estimated as difference between the initial and final concentration of the oil content in the medium. Effect of environmental factors on the growth and degradation of $\mathrm{BH}$ crude oil The effect of $\mathrm{pH}(6.5,7.5$ and 8.5$)$, temperature $\left(15^{\circ} \mathrm{C}, 20^{\circ} \mathrm{C}\right.$ and $\left.30^{\circ} \mathrm{C}\right)$ on the bacterial growth and degradation of $1 \%$ crude oil were studied by using mineral salts medium with BH crude oil.

\section{RESULTS}

\section{Microbiology of oil spilled samples}

The highest microbial population was observed for the sample GS-5. The bacterial, fungal and actinomycetes populations were recorded as $3.0 \times 10^{6} \mathrm{CFU} \mathrm{g}{ }^{-1}, 8.9 \times 10^{4}$ and $4.3 \times 10^{4}$ CFU g ${ }^{-1}$ respectively (Table 1). In gasoline station soil, the maximum $\left(2.98 \mathrm{mg} \mathrm{g}^{-1}\right)$ and minimum $\left(0.56 \mathrm{mg} \mathrm{g}^{-1}\right)$ oil contents were recorded for samples GS-5 and GS-7. The bacterial count in diesel station soil samples ranged between $3.0 \times 10^{5} \mathrm{CFU} \mathrm{g}^{-1}$ for sample DS-1 and $2.1 \times 10^{8} \mathrm{CFU} \mathrm{g}^{-1}$ for sample DS-9. Among the diesel station soil samples the maximum fungal and actinomycetes populations were observed for sample DS-9 with $7.0 \mathrm{x}$ $10^{4} \mathrm{CFU} \mathrm{g}^{-1}$ and $4.7 \times 10^{4} \mathrm{CFU} \mathrm{g}^{-1}$ respectively. In diesel station soil, the maximum of 5.21 $\mathrm{mg} \mathrm{g}^{-1}$ oil content was noticed in sample DS-9 and minimum of $1.65 \mathrm{mg} \mathrm{g}^{-1}$ in sample DS-7. 
Table 1. Microbial distribution and hydrocarbon content in gasoline and diesel station soil samples

\begin{tabular}{ccccc}
\hline Sample & $\begin{array}{c}\text { Bacteria } \\
(\text { CFU/g) }\end{array}$ & $\begin{array}{c}\text { Fungi } \\
(\text { CFU/g) }\end{array}$ & $\begin{array}{c}\text { Actinomycetes } \\
(\text { CFU/g) }\end{array}$ & $\begin{array}{c}\text { Hydrocarbon } \\
\text { content }(\mathbf{m g} / \mathbf{g})\end{array}$ \\
\hline Gasoline station soil samples & & & \\
GS-1 & $8.9 \times 10^{5}$ & $1.1 \times 10^{3}$ & $2.7 \times 10^{4}$ & 0.89 \\
GS-2 & $1.5 \times 10^{6}$ & $3.2 \times 10^{4}$ & $1.7 \times 10^{2}$ & 1.50 \\
GS-3 & $1.1 \times 10^{6}$ & $6.8 \times 10^{3}$ & $2.0 \times 10^{2}$ & 1.06 \\
GS-4 & $1.4 \times 10^{6}$ & $6.1 \times 10^{3}$ & $1.1 \times 10^{4}$ & 1.43 \\
GS-5 & $3.0 \times 10^{6}$ & $8.9 \times 10^{4}$ & $4.3 \times 10^{4}$ & 2.98 \\
GS-6 & $6.8 \times 10^{5}$ & $1.3 \times 10^{3}$ & $9.5 \times 10^{2}$ & 0.68 \\
GS-7 & $5.6 \times 10^{5}$ & $4.4 \times 10^{3}$ & $6.2 \times 10^{3}$ & 0.56 \\
GS-8 & $1.2 \times 10^{6}$ & $4.5 \times 10^{2}$ & $1.0 \times 10^{2}$ & 1.20 \\
GS-9 & $2.0 \times 10^{6}$ & $1.2 \times 10^{4}$ & $3.9 \times 10^{2}$ & 2.01 \\
GS-10 & $8.6 \times 10^{5}$ & $8.1 \times 10^{3}$ & $1.1 \times 10^{2}$ & 0.86 \\
Diesel station soil samples & & & \\
DS-1 & $3.0 \times 10^{5}$ & $1.2 \times 10^{3}$ & $8.9 \times 10^{2}$ & 3.83 \\
DS-2 & $4.3 \times 10^{5}$ & $4.8 \times 10^{3}$ & $5.4 \times 10^{2}$ & 4.61 \\
DS-3 & $8.8 \times 10^{6}$ & $1.2 \times 10^{3}$ & $2.0 \times 10^{3}$ & 5.14 \\
DS-4 & $7.4 \times 10^{7}$ & $1.5 \times 10^{3}$ & $6.3 \times 10^{2}$ & 1.91 \\
DS-5 & $8.6 \times 10^{7}$ & $6.8 \times 10^{2}$ & $3.8 \times 10^{2}$ & 2.42 \\
DS-6 & $6.0 \times 10^{6}$ & $3.8 \times 10^{2}$ & $7.6 \times 10^{2}$ & 2.06 \\
DS-7 & $3.7 \times 10^{7}$ & $5.7 \times 10^{2}$ & $1.8 \times 10^{3}$ & 1.65 \\
DS-8 & $4.3 \times 10^{7}$ & $4.1 \times 10^{3}$ & $4.4 \times 10^{2}$ & 3.56 \\
DS-9 & $2.1 \times 10^{8}$ & $7.0 \times 10^{4}$ & $4.7 \times 10^{4}$ & 5.21 \\
DS-10 & $3.2 \times 10^{7}$ & $7.6 \times 10^{2}$ & $8.1 \times 10^{2}$ & 3.11 \\
\hline
\end{tabular}

Generic wise distribution of bacteria in oil spilled environment

The percentage distribution of different genera of bacteria in gasoline and diesel station soil is presented in figure 1. In gasoline station soil, members of genus Corynebacterium (23.4\%) was at a higher level followed by Micrococcus (14.9\%), Pseudomonas (12.8\%), Alcaligenes and Flavobacterium (10.7\% each), Moraxella and Bacillus (6.4\% each), Enterobacter, Aeromonas and Vibrio (4.2\% each). In diesel station soil, Corynebacterium (36.5\%) was dominant followed by Pseudomonas (14.4\%), Micrococcus and Bacillus (11.1\% each), 
Enterobacter, Flavobacterium and Moraxella (6.3\% each), Alcaligenes (3.2\%), Aeromonas, Acinetobacter and Vibrio (1.6\% each).

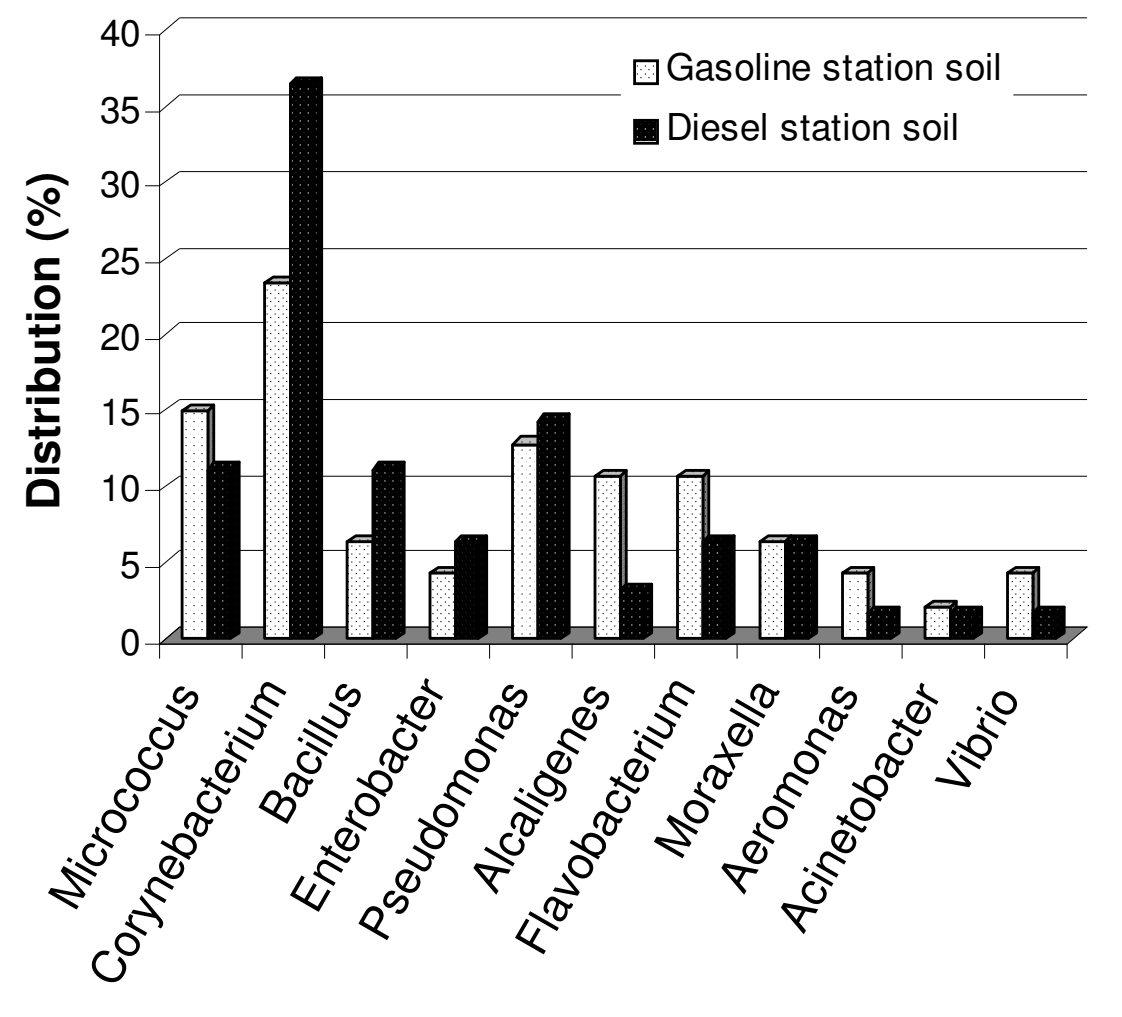

\section{Genera}

Figure 1. Generic wise distribution of bacteria in oil spilled environment.

\section{Biochemical characteristics of bacteria}

The bacterial colonies identified from oil spilled environment were analysed by different biochemical tests and the results are given in figure 2. For gasoline station soil, nitrite reducers $(70 \%)$ were the predominant forms. This was followed by nitrate reducers (65.5\%), ammonia formers (52\%) and catalase producers (50.5\%). Indole producers, 


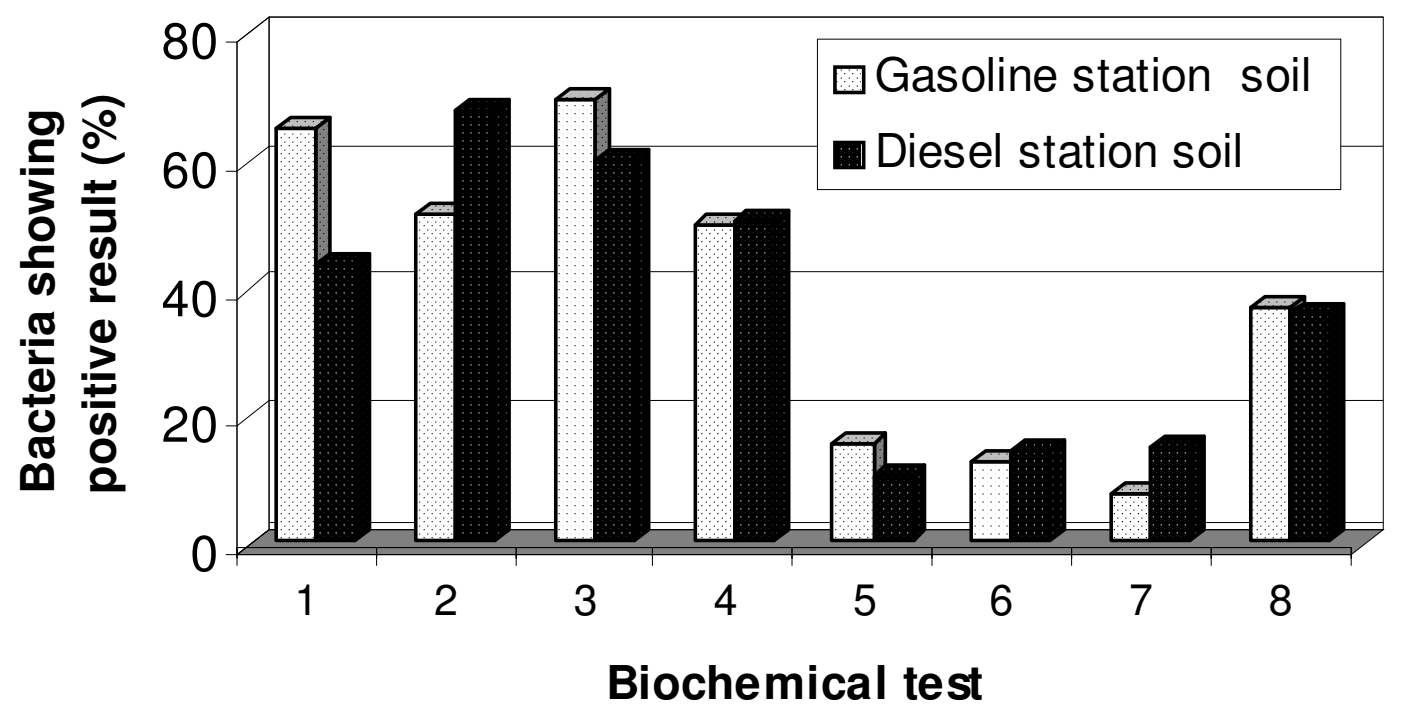

1-Citrate utilisation test ; 2-Vogus Proskauer test ; 3-Methyl red test ; 4-Indole production test ; 5-Catalase test ; 6 -Nitrite reduction test ; 7-Ammonium production test ; 8-Nitrate reduction test

Figure 2. Biochemical Characterisation of bacterial isolates

methyl red and Vogus-Proskauer test positive cultures and citrate utilisers were found at a lesser proportion. In diesel station soil, ammonia producers were at a higher $(68.2 \%)$ proportion than nitrite $(60.3 \%)$, catalase $(51.1 \%)$ and nitrate reducers $(44.3 \%)$ respectively. Indole, Methyl red, Vogus-Proskauer and citrate utilisers were at a lower proportion. 


\section{Bacterial Substrate utilisation}

The physiological activities of the bacterial isolates were studied and the results were presented as percentage of bacterial isolates exhibiting the enzymatic activity (Figure 3 ). For gasoline station soil, very high number of amylolytic bacteria were found $(66.4 \%)$ followed by lipolytic $(49.4 \%)$, caseinolytic $(47.8 \%)$, gelatinolytic $(35.6 \%)$ and the least were urea hydrolysers (19.3\%). Lipolytic bacteria were more $(72.4 \%)$ followed by caseinolytic (54.2\%), amylolytic (49.6\%), gelatinolytic (25.1\%) and the least were ureolytic (11.1\%) for diesel station soil.

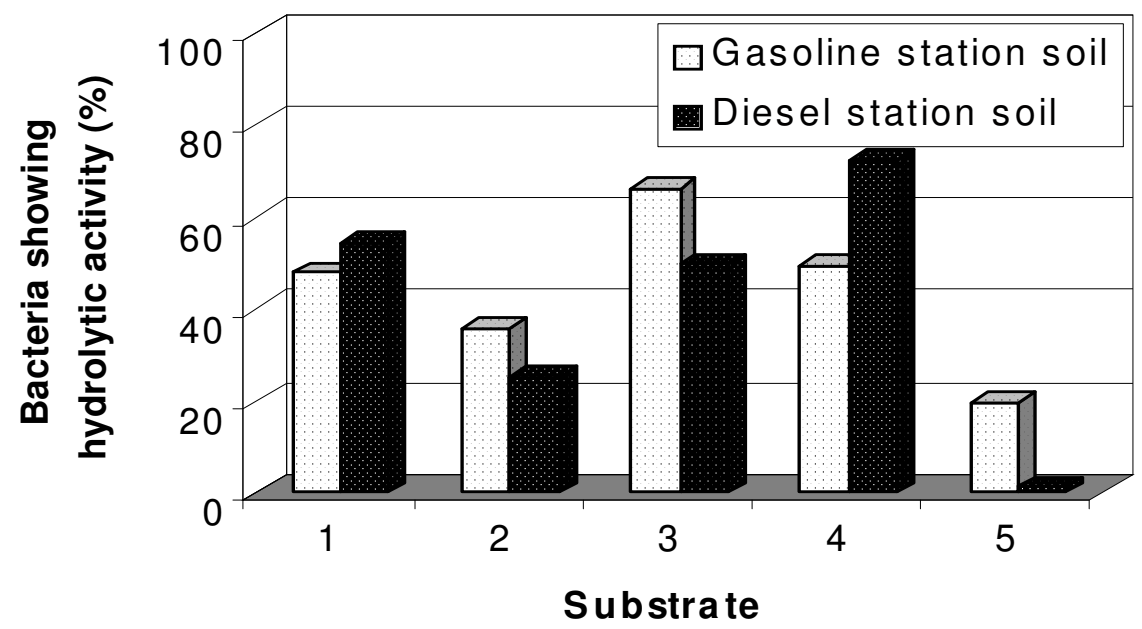

1-Casein; 2-Gelatin; 3-Starch; 4-Lipid; 5-Urea

Figure 3. Percentage of bacteria degrading various substrates. 
Crude oil degradation

The bacterial isolates (130) were tested for their ability to grow in mineral salts medium (MSM) with crude oil as carbon source. Out of 130 isolates, $50.8 \%, 24.6 \%, 20.8 \%$ and $3.8 \%$ showed low, moderate, high, and excellent growth respectively (Table 2). Micrococcus sp. GS2-22, Corynebacterium sp. GS5-66, Flavobacterium sp. DS5-73, Bacillus sp. DS6-86, and Pseudomonas sp. DS10-129, all had excellent growth.

Table 2. Distribution of bacterial genera showing different levels of growth on crude oil

\begin{tabular}{|c|c|c|c|c|c|}
\hline \multirow{3}{*}{ Genera } & \multicolumn{5}{|c|}{ Growth of bacteria on crude oil } \\
\hline & \multirow[t]{2}{*}{ Total No. } & \multicolumn{4}{|c|}{ Optical Density at $620 \mathrm{~nm}^{*}$} \\
\hline & & $0.21-0.4$ & $0.41-0.6$ & $0.61-0.8$ & $0.81-1.0$ \\
\hline Micrococcus sp. & 17 & 10 & 6 & - & 1 \\
\hline Corynebacterium sp. & 45 & 17 & 17 & 10 & 1 \\
\hline Bacillus sp. & 13 & 8 & 1 & 3 & 1 \\
\hline Enterobacter sp. & 6 & 4 & 2 & - & - \\
\hline Pseudomonas sp. & 16 & 4 & 2 & 9 & 1 \\
\hline Alcaligenes sp. & 8 & 7 & - & 1 & - \\
\hline Flavobacterium sp. & 9 & 7 & - & 1 & 1 \\
\hline Moraxella sp. & 7 & 5 & 1 & 1 & - \\
\hline Aeromonas sp. & 4 & 2 & 1 & 1 & - \\
\hline Acinetobacter sp. & 2 & 1 & - & 1 & - \\
\hline Vibrio sp. & 3 & 1 & 2 & - & - \\
\hline Total & 130 & 66 & 32 & 27 & 5 \\
\hline Percentage & 100 & 50.8 & 24.6 & 20.8 & 3.8 \\
\hline
\end{tabular}


Among the four $\mathrm{pH}(6.5,7.5$ and 8.5$)$ tested, $\mathrm{pH} 7.5$ was found optimum for all the bacterial isolates and bacterial consortium (data not shown). Hence the $\mathrm{pH} 7.5$ was selected for further experiments. All the five individual isolates and bacterial consortium showed maximum activity and crude oil degradation at $30^{\circ} \mathrm{C}$ and population also correspondingly increased (Fig. 4). Bacterial consortium showed maximum (78\%) degradation and reached a population size of about $9 \times 10^{8} \mathrm{CFU} \mathrm{ml}^{-1}$ while using $1 \% \mathrm{BH}$ crude oil as substrate.
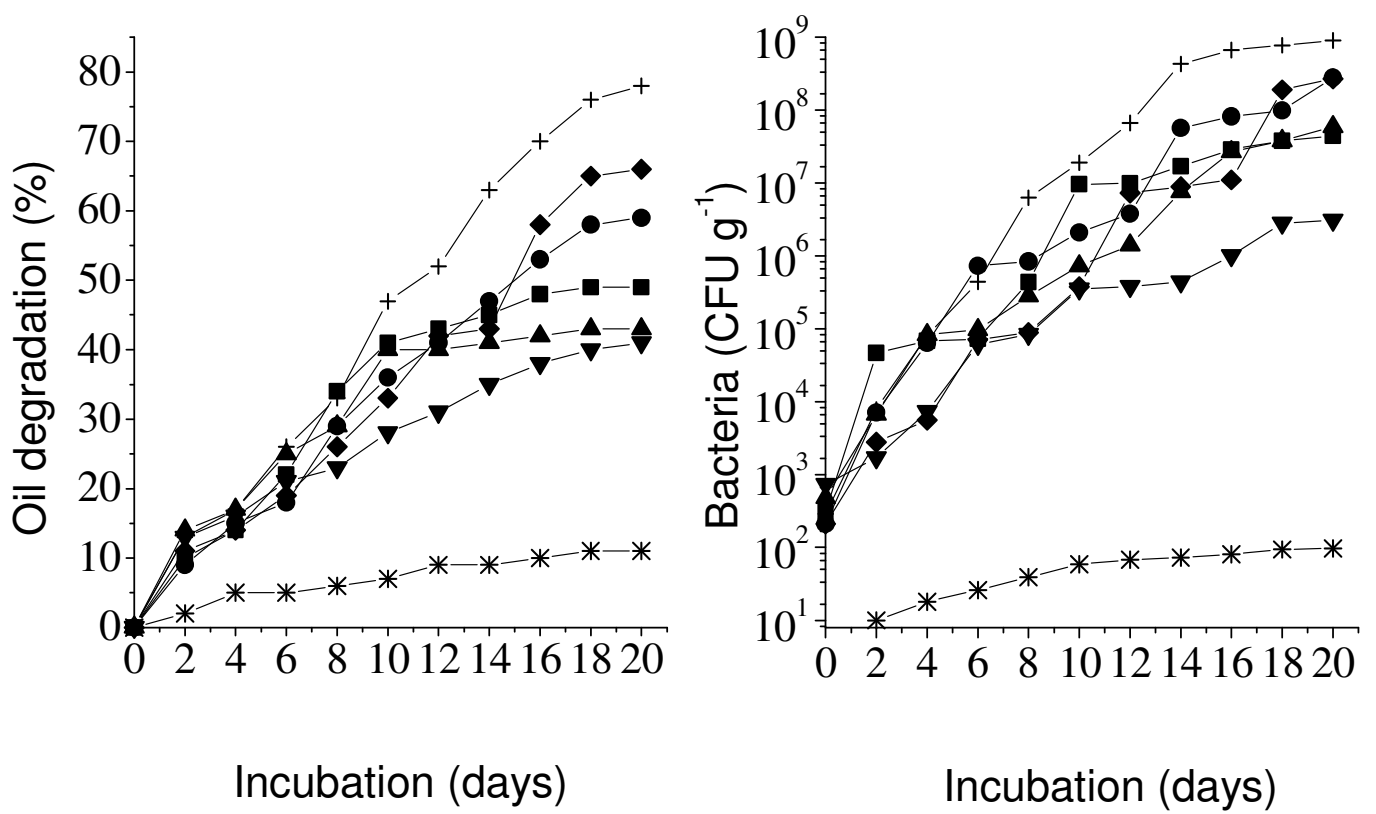

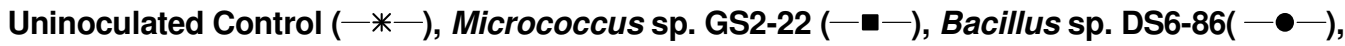

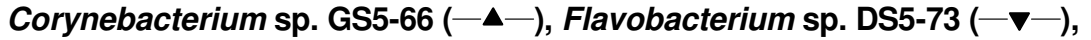
Pseudomonas sp. DS10-129 (- - ) and Bacterial Consortium (-+-).
}

Figure 4. Percentage degradation and bacterial growth at $1 \%$ BH crude oil by selected oil degraders and bacterial consortium in mineral salts medium at $\mathrm{pH} 7.5$ and temperature $30^{\circ} \mathrm{C}$. 


\section{DISCUSSION}

Bacteria, actinomycetes and fungal populations were high in samples GS-5 and DS-9, where higher quantities of oil contents were noticed. Similarly large population of bacteria, actinomycetes and fungi were recorded from oil-spilled environment (Venkateswaran et al. 1993; Wrenn and Venosa 1996; Cabello 1997). Population levels of hydrocarbon utilisers and their population within the microbial community appear to be a sensitive index of environmental exposure to hydrocarbons. In unpolluted ecosystem, hydrocarbon utilisers generally constitute less than $0.1 \%$ of the microbial community and in oil polluted ecosystems they can constitute upto $100 \%$ of the viable microorganisms. The microbial populations quantitatively reflect the degree or extent of exposure of that ecosystem to hydrocarbon contamination (Atlas 1981; Al-gounaim et al. 1995).

In general, gasoline and diesel station soil samples contained Corynebacterium species at higher proportion. The dominance of the genus Corynebacterium revealed that it might have developed the ability to acclimatize to the oil environment. We observed bacteria belonged to diversified groups, which may be due to the oil enrichment. The changes in the dynamic equilibrium state of soil or aquatic environment leads to a corresponding change in microbial population and composition. The added oil enriched for the species that have inherent petroleum hydrocarbon assimilating potential (Bossert and Bartha 1984), whereas the less adapted species among the total heterotrophic population are gradually eliminated, resulting in qualitative shifts in species composition (Amadi 1990).

The biochemical characteristics of the bacteria varied. Austin et al. (1977) reported that the biochemical reactions of the petroleum degraders, as a whole, were not uniform and no pattern of relatedness were discernible based on the reactions. In oil-spilled soil, lipolytic 
forms were present in high numbers, which may be due to richness of lipid source available in the area. Walker et al. (1975) also found an increase in absolute numbers of proteolytic bacteria, as well as lipolytic, chitinolytic and cellulolytic bacteria in oil contaminated subestuary of Chesapeake Bay.

Microorganisms are known to attack specific compounds present in crude oil that is a complex mixture of saturates, aromatics and polar compounds (Bharathi and Vasudevan 2001). An effective degradation of crude oil would require simultaneous action of several metabolically versatile microorganisms with faourable environmental conditions such as $\mathrm{pH}$, temperature and availability of nutrients (Venkateswaran and Harayama 1995). An oil spill in the environment leads to an adaptive process and if metabolically active hydrocarbon utilising microorganisms could be added quickly, the long period before the indigenous population could respond would be reduced considerably. The necessity for seeding with complementary hydrocarbon degrading bacteria arises from the rationale that indigenous microbial populations may not be capable of degrading a wide range of potential substrates in a complex mixture such as crude oil (Chhatre et al. 1996).

It seems that a natural microbial community includes a variety of microorganisms that can degrade, alone or together, most crude oil components, but that some of their degrading ability would not be expressed in a single batch culture owing to unfavorable physiological conditions (Venkateswaran et al., 1995). When mixed cultures are grown in crude oil medium, some organic acids, which prevent the growth of the bacteria, are formed. However, in a mixed culture system, the growth of the organism cannot be regulated because of nutrient stress and competition. The ability of the designed bacterial consortium and individual bacteria with wide crude oil degrading capacity has been employed for the degradation of crude oil. 
The isolated crude oil degraders belong to the genera Micrococcus, Corynebacterium, Bacillus, Enterobacter, Pseudomonas, Alcaligenes, Flavobacterium, Moraxella, Aeromonas, Acinetobacter and Vibrio. The flora reflects the normal heterotrophic bacteria present in soil and native genera seem to be crude oil utilisers. Several other workers also reported on the above genera as hydrocarbon degrading microorganisms (Atlas 1981; Leahy and Colwell 1990; Banat et al. 2000).

In general, bacterial consortium showed maximum percentage (78\%) of degradation of crude oil after 20 days of incubation. Chhatre et al. (1996) reported about $60 \%$ of degradation of crude oil using a semicontinuous crude oil fed reactor using a four member consortium. Several other workers (Venkateswaran and Harayama 1995; Lal and Khanna 1996; Sugiura et al. 1997) showed that a bacterial consortium was able to degrade $28-51 \%$ of saturates and $0-18 \%$ of aromatics present in crude oil or up to $60 \%$ crude oil by mixed consortia. The percentage of biodegradation was significantly higher than that achieved by individual isolates. Among the four different $\mathrm{pH}$ tested, the bacterial growth and percentage degradation of crude oil were maximum at $\mathrm{pH}$ 7.5. Most of the heterotrophic bacteria favor a $\mathrm{pH}$ near neutrality (Atlas 1981). Temperature influences petroleum biodegradation by its effect on the physical nature and chemical composition of the oil, rate of hydrocarbon metabolism by microorganisms, and composition of the microbial community (Atlas 1981). Our studies showed maximum biodegradation activity at $30^{\circ} \mathrm{C}$.

Our research work clearly shows that oil contaminated soil can be a principle source for potent oil degrading bacteria. Genus Corynebacterium was dominant in all the samples 
analyzed. It was observed that bacterial consortium degraded Bombay high crude oil efficiently when compared to the individual bacterial cultures tested.

\section{ACKNOWLEDGEMENTS}

KSM Rahman wishes to thank the Council of Scientific and Industrial Research, New Delhi, India for the award of Senior Research Fellowship. Thanks also to Environment and Heritage Service, DOE for FRDF financial support under the Northern Ireland Single Programme (Ref. WM 47/99).

\section{REFERENCES}

AARANSON, S., 1970. Experimental Microbial Ecology. Academic press, London.

AL-GOUNAIM, M.Y., DIAS, A., AL-ABDULLA, R. and AL-ZAMIL, N. 1995. Effects of petroleum oil pollution on the microbiological populations of the Desert soil of Kuwait. Arab Gulf J. Scient. Res. 13, 653-672.

AMADI, A., 1990. Effects of petroleum hydrocarbons on the ecology of soil microbial species and performances of maize and cassava. Ph.D. thesis, University of Ibadan, Nigeria.

ATLAS, R.M., 1981. Microbial degradation of petroleum hydrocarbons, an environmental perspective. Microbiol. Rev. 45, 180-209. 
ATLAS, R.M., 1995. Bioremediation of petroleum pollutants. Int. Biodeterior. Biodegrad. 21, 317- 327.

AUSTIN, B., CALOMIRIS, J.J., WALKER, J.D. and COLWELL, R.R., 1977. Numerical taxonomy and ecology of petroleum-degrading bacteria. Appl. Environ. Microbiol. 34, 6068.

BANAT, I.M., MAKKAR, R.S. and CAMEOTRA, S.S., 2000. Potential commercial applications of microbial surfactants. Appl. Microbiol. Biotechnol. 53, 495-508.

BHARATHI, S. and VASUDEVAN, N., 2001. Utilization of hydrocarbons by Pseudomonas fluorescens isolated from a petroleum-contaminated soil. Environ. Int. 26, 413-416.

CABELLO, M.N., 1997. Hydrocarbon pollution: its effect on native arbuscular mycorrhizal fungi (AMF). FEMS Microbiol. Ecol. 22, 233-236.

CHHATRE, S., PUROHIT, H.J., SHANKER, R. and KHANNA, P., 1996. Bacterial consortia for crude oil spill remediation. Water Sci. Technol. 34, 187-193.

FERRARI, M.D., NEIROTTI, E., ALBORNOZ, C., MOSTAZO, M.R. and COZZO, M., 1996. Biotreatment of hydrocarbons from petroleum tank bottom sludge in soil slurries. Biotechnol. Lett. 18, 1241-1246.

HOLT, J.G., KREIG, N.R., SNEATH, P.H.A., STANELY, J.T. and WILLIAMS, S.T., 1994. Bergey's Manual of Determinative Bacteriology. Williams and Wilkins Publishers, Maryland. 
KENNEDY, R.S., FINNERTY, W.R., SUDARSANAN, K. and YOUNG, R.A., 1975. Microbial assimilation of hydrocarbons - the fine structure of a hydrocarbon oxidising Acinetobacter sp. Arch. Microbiol. 102, 75-83.

LAL, B. and KHANNA, S., 1996. Degradation of crude oil by Acinetobacter calcoaceticus and Alcaligenes odorans. J. Appl. Bacteriol. 81, 355-362.

LEAHY, J.G. and COLWELL, R.R., 1990. Microbial degradation of hydrocarbons in the environment. Microbiol. Rev. 54, 305-315.

OLLIS, D., 1992. Slick solutions for oil spills. Nature 358, 453-454.

RAHMAN, K.S.M., BANAT, I.M., THAHIRA, J., THAYUMANAVAN, T. and LAKSHMANAPERUMALSAMY, P., 2002. Bioremediation of Gasoline contaminated soil by a bacterial consortium amended with poultry litter, coir pith and rhamnolipid biosurfactant. Bioresource Technol. 81, 25-32.

SUGIURA, K., ISHIHARA, M., SHIMAUCHI, T. and HARAYAMA, S., 1997. Physicochemical properties and biodegradability of crude oil. Environ. Sci. Technol. 31, 45-51.

VENKATESWARAN, K. and HARAYAMA, S., 1995. Sequential enrichment of microbial populations exhibiting enhanced biodegradation of crude oil. Can. J. Microbiol. 41, 767-775. 
VENKATESWARAN, K., HOAKI, T., KATO, M. and MARUYAMA, T., 1995. Microbial degradation of resins fractionated from Arabian light crude oil. Can. J. Microbiol. 41, 418-424.

VENKATESWARAN, K., KANAI, S., TANAKA, H. and MIYACHI, S., 1993. Vertical distribution and biodegradation activity of oil degrading bacteria in the Pacific Ocean. J. Mar. Biotechnol. 1, 33-39.

WALKER, J.D., COLWELL, R.R., HAMMING, M.C. and FORD, H.T., 1975. Extraction of petroleum hydrocarbons from oil-contaminated sediments. Bull. Environ. Contam. Toxicol. 13, 245-248.

WRENN, B.A. and VENOSA, A.D., 1996. Selective enumeration of aromatic and aliphatic hydrocarbon degrading bacteria by a most probable number procedure. Can. J. Microbiol. 42, 252-258 